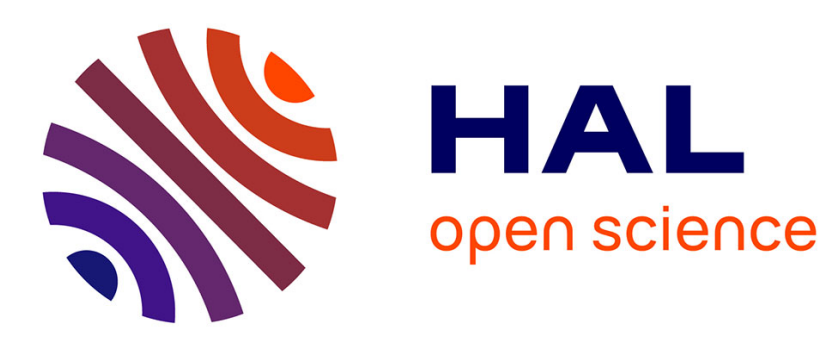

\title{
French and Spanish colonial policy in North Africa: revisiting the Kabyle and Berber myth \\ Mohand Tilmatine
}

\section{To cite this version:}

Mohand Tilmatine. French and Spanish colonial policy in North Africa: revisiting the Kabyle and Berber myth. International Journal of the Sociology of Language, 2016, 2016 (239), pp.95-119. 10.1515/ijsl-2016-0006 . hal-01824567

\section{HAL Id: hal-01824567 https://hal.science/hal-01824567}

Submitted on 27 Jun 2018

HAL is a multi-disciplinary open access archive for the deposit and dissemination of scientific research documents, whether they are published or not. The documents may come from teaching and research institutions in France or abroad, or from public or private research centers.
L'archive ouverte pluridisciplinaire HAL, est destinée au dépôt et à la diffusion de documents scientifiques de niveau recherche, publiés ou non, émanant des établissements d'enseignement et de recherche français ou étrangers, des laboratoires publics ou privés. 
Mohand Tilmatine*

\section{French and Spanish colonial policy in North Africa: revisiting the Kabyle and Berber myth}

DOI 10.1515/ijsl-2016-0006

Abstract: The French colonial presence in North Africa gave rise to a view that was founded on attributing certain - supposedly distinctive - qualities to the Kabyle people (Algeria) and the Berber people in general (Algeria and Morocco). This became known as "the Kabyle (or Berber) myth" and was propagated both by North African nationalists and by the academic world in order to validate their accusations against the colonial powers of practicing a "divide and conquer" policy. What's more, from the outset, the French and Spanish colonial governments, by empowering Arabic as an imperial and dominant language to the detriment of the peripheral and low prestige Berber languages, greatly contributed to the widespread acceptance of a further myth, i. e., North Africa was "Arab and Muslim”. These myths then became a key argument used by the post-colonial governments to deny the distinctiveness of the Kabyle people, and Berbers in general, hence justifying rejecting their demands for linguistic and cultural recognition. In recent years, however, the Berber people have reacted to these myths; we have witnessed the birth of a resistance movement, the uprising in Algeria (Kabylie) and the development of cultural pride and identity. Surprisingly, these events have caused us to reflect anew on the Berber myths of the colonial period.

Keywords: French and Spanish protectorate, North Africa, Berber myth, Kabyle myth, Berber identity

\section{Introduction}

The aim of this article is to analyze French and Spanish cultural policies with regard to the Arab and Berber populations under their control during the colonial period (Algeria: 1830-1962; Morocco: 1912-1956). In particular, the study will explore whether the Berbers received preferential treatment, as is commonly thought, or alternatively, whether the actions of the colonial powers strengthened processes of Arabization in North Africa.

*Corresponding author: Mohand Tilmatine, University of Cadiz, Cadiz 11001, Spain, E-mail: mohand.tilmatine@uca.es 
Among the useful analytical concepts to be examined are the so-called Kabyle myth in French Algeria and the Berber policy in Morocco, that peaked with the Berber Dahir [Berber decree] of 1930, which are often presented as part of France's “divide and conquer" policy as well as the Christianization and de-Islamization of the Berbers.

Finally, in relation to the present-day and the impact of this supposed French policy on the post-colonial North African states, this article will discuss to what extent a particular reading of history shaped the way events unfolded during the last 40 years and added additional layers to the older Kabyle myth and the skewed view of France's Berber policy.

The history of the Spanish Protectorate in the north of Morocco is tied in diverse ways to that of the French colonial project in Algeria. To begin with, both countries shared the common objective of occupying Morocco, which was decided upon at the Algeciras Conference in the year 1916 (De la Torre del Río 2007).

Similarities are especially apparent with regard to cultural and linguistic policies which were undoubtedly inspired by long-standing French practice in Algeria.

From the outset, both France and Spain viewed the North African lands as predominantly Arab. Hence, their policies would constitute, simultaneously, the promotion of the French and Spanish languages in their respective areas of control, and the encouragement of Arabization.

This approach becomes clearer when examining the concrete application of colonial policy by the Bureaux arabes ['Arab Offices', hereafter BA] in Algeria and the Delegación de Asuntos Indígenas [Offices of Native Affairs] in Spanish North Morocco.

\section{France's Berber policy}

\subsection{The Kabyle myth}

According to the traditional European and North African literature (Kaddache 1972: 276), a network of research centers, archives and journals dedicated to the scientific study of Berbers was created to set ethnic boundaries between Arabs and Berbers, and to use such a division to justify colonial cultural, economic and social policies.

Most scholars and researchers tend to focus on the stereotypical colonial images of the 'good' Kabyle and the 'bad' Arab and explore the circumstances in which they arose, as well as the intellectual and ideological influences that underpinned them. 


\subsubsection{Arab/Berber dichotomy}

Such a dichotomous categorization, i. e. Arabs versus Berbers, continues to evoke preconceived and largely confusing ideas. This issue increases suspicion between Arabic and Berber speaking populations in North Africa, especially in the countries of Algeria and Morocco, both home to significant Berber speaking communities.

The Arab/Berber dichotomy was a fundamental tenet in the colonial worldview and discourse and has remained central to the postcolonial discourse that draws from it in order to explore and interpret the cultural and sociological reality of Algeria and Morocco. "North African history has often been narrated in academic and political discourses through recurrent series of binary oppositions" of which the opposition “Arab/Berber" is perhaps "the most central” (McDougall 2003: 66).

The so called Kabyle myth was born largely in the literature of military men such as Aucapitaine and Hanoteau (Ageron 1968: 266-277). According to certain current and widespread ideas in the research works on the colonial period, France needed to side with the Berbers against Arabs and to administer Berber areas in a different way.

Did France really have a Berber policy in Algeria and Morocco which favored Berbers over Arabs or was this a "mirage” (Ageron 1960: 315, 1968: 267-277) and, in fact, a distortion of the sociological realities by poorly informed scholars, notwithstanding (or perhaps as a result of) the large number of studies on the subject?

Since the literature on the Berber policy of France was essentially the outcome of infinitely repeated preconceived ideas, it is necessary to understand the intellectual climate in which such a policy was able to grow. This discourse, which reached its peak during the colonial period, continued to serve the post-colonial North African ruling elites, legitimizing the rejection of a linguistic and cultural reality and thus minimizing Berber demands. Furthermore, this discourse attempted to negate the underlying beliefs and values of the Berber-dominated society, and impose a new vision of exclusively Arabic and Islamic cultural and political values. There is a very rich bibliography, largely in French but increasingly in English, about Berbers in general, addressing these topics - (Lorcin 1995; McDougall 2003, 2010; Boudraa and Krause 2007; Hoffman 2010; Hoffman and Gilson Miller 2010; Maddy-Weitzman 2011, etc.)

\subsubsection{Berber qualities}

Following Ageron (1971: 51) "most French writers" who subscribed to the Kabyle myth stated that the Berber "race" possessed such eminent qualities as "frankness, loyalty, sense of economic interests and absence of aggressive fanaticism". 
The same author also underlined the ancestral capacity of Berbers in the work place: "It was the Berber plough that made of Africa the granary of Rome." This literature also emphasized their desire for freedom: "the Berber is, of tradition, a free man who dearly loves his freedom and is always ready to fight to defend it". They were also celebrated as "true democrats" and "free citizens whom we cannot lead only by force".

Emphasis was also placed on the physical characteristics of the Kabyle people and their "European" appearance: "While the Arab has black hair and black eyes, many Kabyles have blue eyes and ginger hair” (Daumas and Fabar 1847: 20). Similarly, Ageron writes, "Were they not the 'pure white Berbers', the most untamed, those who'd had the least contact with imported civilizations? Were they not 'tall and slender', a white, people with a conical thorax, and the features of our own inhabitants of Auvergne?” (Ageron 1971: 53). Besides their physical appearance and exemplary qualities as sedentary and hard-working farmers, the Kabyles lived, as recorded in this literature, in "mini-republics" according to democratic social models of organization: "Le Moyen Atlas, c'est la démocratie sur toute la ligne; seul le peuple commande et seul le peuple parle et seul le people chante" [The Middle Atlas is democratic in the true sense of the word; the people alone rule, the people alone speak and the people alone sing] (Ageron 1971: 53-54). Whether they are democrats or conservatives, certain political virtues are attributed to Berbers that are not attributed to Arabs.

\subsubsection{Less islamized}

Berbers especially distinguished themselves, according to colonial literature, by accepting a low degree of Islamization and possessing "a real moral code, sometimes distinctly set against Islamic morality". This attitude can be explained, according to the Colonial discourse, by their reluctance to participate in jihads ('holy wars') and their "almost equal aversion to Christians and Arabs" (Daumas and Fabar 1847: 193).

In any case, in the opinion of the majority of writers, "they were not fanatical" and "pure Berbers were barely practicing Muslims and almost never prayed” (Ageron 1971: 52).

\subsubsection{Customary law}

Berber hostility to Sharia law was asserted, without nuance, as a characteristic of their race. Their customary law was said to be "non-Koranic and often anti- 
Koranic” (Ageron 1971: 54). In Renan's view (1873: 61), large numbers of Kabyle people "while appearing to be irreproachable Muslims in regards to dogma, distanced themselves from the Koranic civil law stating, and correctly so, that the (Koranic) prescriptions were made for a very different country from their own and for a people who didn't share their way of life. This is a rarity in Islam!”

According to Glay, "all Berbers view their national customs as law and we can affirm that everywhere in Morocco the Berbers only submit themselves to the Sharia when we force them to by assimilation to other Muslims" (Ageron 1971: 52).

The Contrôleur Civil Bruno (civilian administrator in protectorate Morocco) formulated it as follows: "The izref [Berber customary law] is more often in accordance with the spirit of our Code than the laws of Islam; so we would rather have them continue to use, under our control, their civil customs" (quoted by Ageron [1971: 54]). So, a number of authors were citing a Sheik of the Moroccan High Guir region who over years repeatedly claimed that Berbers do not abide at all by the Sharia: "We have buried the Sharia. Whoever refers to or makes use of it in our country will regret it" (Ageron 1971: 54, note 4).

Moreover, the application of customary law was widespread in Kabylia and it is common to find measures, decisions, sayings and proverbs that go beyond the Koranic rules when deemed more useful for the community. The famous Kabyle cleric and philosopher, Chikh Mohand (Muhend U Lhusin; circa 18371901), is well known as sharing this point of view, and oral traditions yield many anecdotes demonstrating his pragmatism with regard to the application of the Koran and the Sharia (Mammeri 2005).

One of the more interesting practices, clearly far removed from Muslim law, was the disinheritance of women in Kabylia in contrast to the Islamic laws (Sharia) which allowed women to inherit. In fact, the division of inheritance in the Islamic tradition is a complex and highly detailed subject with rules defined by Surah 4 (Koran 4:7, 11, 12, 33, 176). In general terms, the female share is half that of the males.

In spite of these clear instructions with regard to the inheritance rights of the woman, the Kabyle tribes chose to deny women their inheritance. This was validated by a decision made by common consent and formalized in a document in 1749 , the result of a common accord of several Kabyle tribes. ${ }^{1}$

1 Regarding reasons and social and political motivations and implications of this decision, see Patorni (1895), Hacoun-Campredon (1921) and Nait-Djoudi (2001). 


\subsection{Hatred towards the Arabs}

The supposed hatred of the Kabyles towards the Arabs allegedly made them eligible for offers for better conditions, integration, assimilation and even a natural merging with the French civilization, and this formed the basis of the French policy.

Dr. Bodichon saw the supposed hatred between Kabyles and Arabs as being exploited to the advantage of the French:

France has developed this antagonistic instinct between Arabs and Kabyles and conveniently pitted the two races against each other. Between the French and the Kabyles the conditions for merging and assimilation are easier and more natural. With regard to the Arabs, if, after instructing them how to be civilized, they persist in wanting to remain Arabic, then we would have to do what the Anglo-Saxons did to the Indians. (Ageron 1960: 313, note 3).

\subsection{The Bureaux arabes}

Beginning in 1844, the army administered the majority of natives as well as the small number of Europeans (six percent in 1858), reducing the civilian territory to the coast via the special unit, the Bureaux arabes (BA).

The primary functions of the BA were to take part in the conquest and the "preservation of peace" (Yver 1955: 570) and to maintain order in the Berber regions where they were active. These objectives were clearly indicated by general Daumas, founder of the BA: "This institution has, as its objective, to ensure the long term pacification of tribes by a just and regular administration, to prepare the way for colonization and trade by the preservation of law and order, to protect all legitimate interests and to improve the well-being of the natives" (Yacono 1953: 15, 1992: 1658).

BA members were required to have a thorough knowledge of the native society and its interests, and to understand the forces that acted upon the society to define, in every domain, the actions that might transform it in order to bring the natives "to accept our domination, and the accompanying elements of government, with the least possible aversion" (Foucher 1858: 25-26). There were 40 BA branches in 1850 and 49 in 1870, covering vast regions. They were controlled by 150 to 200 officers, assisted by doctors, khodja (Algerian secretaries) and chaouch (orderlies), and supported by small groups of Spahis on horse-back and auxiliaries on foot. Their initial mission was military intelligence: "Avoir, pour ainsi dire, la main sur le pouls des tribus (note du Ministère de la Guerre 1857)" [to have, as it were, their finger on the pulse of the tribes (War Ministry note, on 1857)] (Rivet 1991). 
Isolated in the midst of largely hostile tribes, the BA officers had to be, simultaneously, warriors, diplomats, administrators, public works directors, tax inspectors, agricultural advisers, judges and education managers. In Lyautey's words, you could only succeed if you were "an intelligent civilian in the skin of a serviceman” (Yacono 1992: 1658). Although it was not among their main objectives, the BA assisted in the Arabization of patronymic names and introduced other Arabization programs in northern Morocco, especially during the second part of the twentieth century.

\subsection{The project of an Arabic empire}

On 17 September 1860, Napoleon III set foot on Algerian soil with an ambitious project in mind: an Arabic kingdom which would extend from Algiers to Baghdad under the protection of France - a kingdom where equality between natives and Europeans would reign.

He surprised French officials by declaring that their first duty was to concern themselves with "the well-being of the three million Arabs who fate has brought under our domination". With this declaration there was an impressive reversal of the situation; the "colonized" came to the fore, almost on the same level as the "colonizers", "the natives metamorphosed into Arabs" (Rivet 1991). Moreover, he discovered that 15 million Arabs, from Algiers to Baghdad, "lived under the Ottoman yoke” providing a potential for France's guiding hand. He thus envisaged an Arab entity centered in Damascus, one that would be autonomous but not independent of the Sublime Porte (the court of the Ottoman Empire) and similar to the status of Egypt. At the head of this planned entity would be the Emir Abd el-Kader, exiled in Damascus since 1852 and who intervened in 1860 to save the Christians there from slaughter.

The Emir, however, refused categorically to consider this proposition, reiterating his intention to dedicate the rest of his life to prayer and the study of Islam. From France's perspective, Algeria was seen as an Arab nation and as such held great symbolic value and strategic importance. Though it never saw the light of day, much has been written on the Arab entity, which was developed as part of French cultural policy in Algeria and aimed at creating a client Arab empire under France's domination. Historians indicate that this political choice was supported or initiated in the time of Napoleon III (Rey-Goldzeiguer 1977; Ageron 1970). Having been the first among European leaders to believe in the possibility of reviving an Arab Empire at the expense of the Ottoman Empire, it is not impossible that Napoleon III considered it the destiny of the Napoleonic Dynasty, and in the interests of France, to help in its reconstruction. 
It was clear that for the Emperor, this nation was Arabic and nothing more: “[...] notre possession d'Afrique n'est pas une colonie ordinaire, mais un royaume arabe" [The country we have taken in Africa is not an ordinary colony but an Arabic Kingdom], declared Napoleon III on his arrival in Algiers on 18 September 1860 (Spillmann (1972: 3). He then made the same statement on 6 February 1863: "Je le répète, l'Algérie n'est pas une colonie proprement dite, mais un royaume arabe. Les indigènes ont comme les colons un droit égal à ma protection et je suis aussi bien l'Empereur des Arabes que l'Empereur des Français” [I repeat, Algeria is not a colony as such, but an Arabic Kingdom. Natives and colonialists have an equal right to my protection and I am both Emperor of the Arabs as well as Emperor of the French] (Spillmann 1972: 4).

Napoleon III was in no way the only arabophile of this period. Numerous intellectuals and Arabists supported his policy, one of the best known and most important being Ismaÿl Urbain, a convert to Islam (Urbain 1861; Rey-Goldzeiguer 1977; Lorcin 1995, note 65; Levallois 2001).

\subsection{The French Berber policy and the Dahir of 1930 in Morocco}

It is important to remember that the political status of Algeria was not equal to that of Morocco. Algeria was considered an integral part of France and an overseas department, and assimilation was the official aim of French policy in Algeria. Morocco, however, was shared rule under France and Spain meanwhile Algeria was only under French domination, with all the implications this supposes. According to North African history specialists such as Ageron (1971: 50), the Berber policy introduced by France in the Moroccan Protectorate differed from the one practiced in Algeria under the name Kabyle policy. As stated by the same author, quoting military sources of the time, the Moroccan Berber policy was based on one essential idea: "the Moroccan people are not Arabic" and they remained a very superficially Islamized, and very partially Arabized, Berber unit which could and would be exploited to the great benefit of France. According to these sources and many other authors, the still non-arabized Moroccan people would attain French civilization, due to not being labelled "Arabic".

In Morocco, this policy found expression in the renowned Berber Dahir of 16 May 1930 signed and propagated by the Sultan of Morocco on the insistence of the Resident General. This decree became notorious in many aspects in view of the reactions its publication provoked. The actual name of the decree is "Dahir du 16 mai 1930, réglant le fonctionnement de la justice dans les tribus de coutume berbère non pourvues de mahakamas pour l'application du Chrâa" [Dahir of 16 May 1930, structuring the operation of justice in tribes 
of Berber custom not provided with mahakamas ('Courts of justice') for the application of Sharia].

All observers agree that this decree swiftly catalyzed the birth of Moroccan nationalism. These reactions no doubt surprised French Authorities who saw the decree as merely one among many (Lafuente 1999: 187-279).

In fact, this Dahir was aimed at adapting "Berber justice" to the new conditions of the time, therefore adjusting it to the spirit of the policy inaugurated in Morocco by Lyautey who signed the Dahir of 11 September 1914, which included modifications of certain legal points pertaining to the system of justice in the Berber lands: Berber tribes were to be administered according to their own laws called 'urf (Arabic) or izref (Berber). Nevertheless, the decree of 1930 raised such a general outcry among Arab and Muslim nationalists worldwide that under the pressure of the national movement and a segment of the Muslim world, France, along with the King of Morocco, had to modify the Dahir's content with a further Dahir in 1934 (Lafuente1994: 2190-2191). According to important sectors of the Nationalist Movement, under strong influence of the Arabic Nahda Movement and their supporters, the objectives of the Berber policy were to sow ill-feeling and stir up ArabBerber tensions, to de-Islamize and Christianize Berbers by excluding the Sharia and finally, to alienate them from Islam and the Arabic language (Lafuente 1994: 2184).

An international campaign was launched against the Dahir and supported by Arabic nationalist activists and institutions such as the General Islamic Congress which met in 1931 in Jerusalem. ${ }^{2}$ This campaign emphasized the Dahir's alleged purpose of Christianizing the Berbers who constituted a majority among the Moroccan population. The objective was to dramatize the situation in order to stir the emotions of Muslims around the world and to take advantage of the psychological and political context of the moment in order to present the Dahir as an attack against Islam.

For that purpose, Arab nationalist activists seized the opportunity to present it as a proselytizing stratagem with the material and moral support of the Rabat Catholic Church. ${ }^{3}$ German scholar and Arabist, Kampffmeyer (1934: 74-86), in an article entitled Der Widerhall des Berber-Dahirs in der Islamwelt [Teh response of the Berber Dahir in the Islamic World], makes a similar argument amplifying it with very detailed testimonies of the mobilization of Muslims "across the Muslim world from Marrakech to Java” (quoted by Kampffmeyer [1934: 77]). Similarly,

2 http://amazighworld.org/countries/morocco/documents/dahir_berbere/lettre-du-congres-isla mic_ar.php.

3 Cf. The first three years of the Berber crisis, in http://said.hajji.name/en/book-berb3ans.html). This report, issued to the press of the Middle East was drafted on 16 May 1933, the date of the third anniversary of the promulgation of the Berber Decree. 
Hoisington (1978: 434) argues that by placing the application of customary law (urf) on a solid legal footing the Dahir posed a threat to Islam and to the unity of the sharifian Empire. It was seen by Moroccan nationalists as "an obstacle to the continued penetration of the Berber lands by the 'revealed' or Koranic law". Others, such as David Hart (1997: 11-33), though giving little consideration to the Christianization of the Berbers, saw the Dahir as part and parcel of a de facto policy, that of "divide and conquer", which the French had already learned in Algeria.

The most virulent reactions, however, always came from the Arab nationalist camp, which see in it (the Dahir of 1930) the clear expression of a determined will to separate "three quarters of the population of the country from the Muslim law" and, consequently, from the temporal and spiritual authority of the Sultan of Morocco (Lafuente 1984: 90). Other nationalists further stated, “[...] the Berber idea may be considered as one of the most dangerous colonialist concepts known to humanity, past or present, due to the way those in power impose their policy of integration on the weak ones". "Particularly prominent in this sense were the articles published as booklet in France by some Moroccan nationalists under the pen name Mouslim Barbari and with the title Tempête sur le Maroc [Storm on Morocco] (1931). Their/its main objective was to launch a campaign of dramatization against the Dahir and its contents (Mouslim Barbari 1931).

\section{Spain's cultural policy in Northern Morocco}

It is important to point out that French and Spanish cultural policies differed in some points: the effects of the BA in Algeria and those of the Delegacion de Asuntos Indígenas [Native Affairs] in the north of Morocco as well as the implications of the Berber Dahir appear not to have had the same repercussions in the Spanish part of the north of Morocco as in other regions of this country.

From the beginning of their occupation of the North African territories, France, and later Spain, attached great importance to the development of programs to learn the native Berber languages and to the creation of structures in order to improve their knowledge of the mentality and the psychology of the indigenous populations with the aim of having them serve in various civil or military administrations (Koller 1949). The establishment of the Protectorate in the north of Morocco in 1912 marked for Spain the commencement of control policies in the territory designated for its rule, but also for control of its

4 Un Berbère musulman quoted by Abderraouf Hajji, La question berbère en 3 ans. Chapitre 14. Le Maroc face aux aléas de l'histoire. http://said.hajji.name/fr/book-berb3ans.html. 
population. In the case of the Spanish Protectorate in northern Morocco, as in Algeria at the beginning of colonization, the power and influence of the Spanish administration were monopolized or directly controlled by the military (Villanova 2005). From very early dates, the administrations of both countries, France and Spain, viewed education as an important factor in the process of achieving and increasing control over the population, viewing it as one of the ways to achieve political, economic and social penetration of the country, defined as "peaceful penetration" and "pacification”. The Spanish Royal Order of 17 January 1914 created classes of Chelja (Berber) in the Arabic Academy of Melilla bearing in mind "that the natives of that territory spoke, as their mother tongue, the Riff Berber (Chelja) and that the knowledge of this language for the Spanish should produce considerable benefits and advantages in relationships and the process of penetration". In the case of both France and Spain, the objective of the colonial administration was to use education as an instrument in order to control the population. In this respect, a number of professions were seen as having particularly crucial roles to play: e.g. inspectors, translators, doctors and teachers (Tilmatine 2009/2010; Gónzalez 2012: 69).

Two educational projects were proposed, each offering an alternative on the basis of different models. The first was elaborated by the Spanish Consul López Ferrer, former Alto Comisario [High Commissioner] (1931-1933). He presented before having been designated as consul, a report to the Spanish Government on 6 March 1912 entitled: "Notes for the study of public instruction in Morocco, especially in Tetouan", in which he advocated the adoption of a Spanish School model combined with the teaching of the Arabic language and Islam. This model was named the Hispano-Arabic school (González 2012: 71). The second model was put forward by the commander Cogolludo in October 1913 in a report to the Alto Comisario regarding the administrative organization in Tetouan following the political and military occupation by Spanish troops. In this report, the commander favored intervention in the most traditional educational sector: the Koranic medersa [school]. He proposed "instruction with a Moroccan accent, whose administrative competence had to be at the expense of the majzen as a way to dissociate the Spanish input from any religious connection". The aim was also to promote and develop the knowledge of Islamic doctrines among Muslims (González 2012: 75).

\subsection{Arabic in Algerian and Moroccan secondary schools}

Generally, for Algerians who had access to education, Arabic became a compulsory subject in secondary schools. Even prior to World War II, it was Arabic and 
not Berber that was introduced in the schools by the Pères Blancs [White Fathers]. Far from developing the Amazigh (Berber) languages, colonial policy always took the "Arabness" of the North African countries as a fundamental fact.

The orientation of education in the northern Moroccan Protectorate was always based on Arabization which promoted elementary education in Arabic to be taught mainly by Moroccan teachers. From that educational system emerged a Moroccan baccalaureate, established following the Egyptian model and unique to Morocco in the context of an increasingly Arab-friendly political environment (Valderrama 1956: 981-982).

The Arabization of Morocco was no longer a plan for the future. Thanks to the cultural policy of the Spanish Protectorate, it was already underway. Valderrama (1956: 11) pointed out that due to Arabization and the fact that the Moroccan primary and secondary education programs had been developed in the Arabic language, "a group of perfectly prepared young teachers was given full responsibility to initiate the tasks they would undertake in the Morocco of tomorrow, which has already become the Morocco of today".

\subsection{Translation schools for dialectal Arabic and Berber}

Since the beginning of the Protectorate, Spain welcomed the commitment of the military to learn local languages. It is essential, however, to emphasize, with regard to scientific production, that the Spanish military had an infinitely less important role than that of the French in Algeria. They limited their efforts largely to the management of education in spoken Arabic (and occasionally in the Amazigh languages) in the different schools of the Spanish Protectorate. The French objective was, however, in no uncertain terms, to turn Algeria into a French department. ${ }^{5}$ France deployed significant means to reach this objective, including resorting to academics and specialists to ensure a successful outcome to the task of the Arabic offices. Spain, on the other hand, limited its involvement to military action, investing the Army with full power in the Protectorate. It was thus not surprising that relatively few academic works on Berbers or Morocco in general were produced during the period of the Spanish Protectorate, and that the quality of these works was relatively mediocre, especially when compared with the work of French scholars in the French occupied zones/regions of Morocco (Hart 1999: 113).

5 From 1848 until independence, the whole north region of Algeria was administered as an integral part of France. Three civil territories - Algiers, Oran and Constantine - were organized as French departments (local administrative units) under a civilian government. 
However, there is no doubt that in both Algeria and Morocco, Berber was always used for functional and practical purposes and not meant to become a developed tool for the education of the Algerian or Moroccan Berber.

Hence, training centers were developed in North Africa for military and paramilitary corps and designated for the purpose of teaching North African mother tongues: dialectal Arabic and the Amazigh languages. The first experiences in teaching the so called "Vulgar Arabic" already began as early as 1888 in Ceuta under the management of the military government of the city. The fundamental objective of these centers was to respond to the needs of the military government. They were an arm of the Ministry of Defense and worked under the direction and the control of the local military governors.

Among the different educational institutions working under the regime of the Spanish Protectorate, two are of particular interest because of their efforts to integrate the teaching of Amazigh (Berber) into their programs: La Academia de Árabe vulgar de Melilla [The Academy of Vulgar Arabic of Melilla] (1904) and the Academia de Árabe y Bereber de Tetuán [Academy of Arabic and Berber of Tetouan] (1929); the latter changed its name in 1938 to Centro de Estudios Marroquies [Centre of Moroccan Studies] (Tilmatine 2001). From the onset of Spanish involvement in Morocco, it was clear that the Protectorate would consider the Islamic religion and the Arabic language as organic bases (bases orgánicas) for its cultural policy (Valderrama 1956: 15). As a result, the cultural action program was developed following basic principles and applied gradually in successive stages:

(a) A single system of instruction, without regional or linguistic differentiation.

(b) Arabic as vehicle of cultural formation, also among the Berber speaking tribes. All schools would be named "Hispanic-Arabic". There would be no "Hispanic-Berber schools".

(c) The school experience would take advantage of Muslims in the seats of power in the cultural promotion of the zone.

(d) The teaching of the Koran would be fundamental in Primary School Education.

(e) Care would be taken in teaching the Arabic language and the Islamic religion, parallel to the construction of mosques and religious education in general.

(f) Traditional religious education and the right to train Ulemas [moslem scholars] and jurists would be promoted through modernizing the centers and the systems. (Valderrama 1956: 63)

What's more, the Spanish even favored running their administration in Arabic and supported the teaching of Arabic in all Spanish Trade Schools, as well as the Military and Naval Schools (Valderrama 1956: 909-910). 


\subsection{Spanish Delegación de Asuntos Indígenas for the north of Morocco}

The similarities between the policies of the Spanish Protectorate and those of France appear logical considering the two powers shared Moroccan rule. It is also clear that there was a huge imbalance between these colonial powers in that France, as colonial power in North Africa, had already gained much more experience, thanks to its control of Algeria. However, specialists agree that the Spanish policy was little more than a reflection of the French policy in which it aspired to define itself. This aspiration affected many domains including the administrative structures. The rank of the High commissioner was supposed to correspond to the French Resident General while the Military Corps of Controllers (Interventores) of the Delegación de Asuntos Indígenas [Office for Native Affairs] had to exercise the same functions as those of the Algerian BA and thus represented the structure of the tribal administration in the entire zone.

This structure was directly replicated from the French system of the BA. ${ }^{6}$ For the express purpose of replication, a mission had been entrusted to a Spanish serviceman, the Captain of artillery of Melilla, Lobera Girela (1905), the former influential founder-editor of the Melilla newspaper El Telegrama del Rif, to study the Algerian BA and file a detailed report to his superiors.

The 43-page report, drafted after his mission in 1905 and published the same year in Melilla, is divided in two parts. The first part pertains to the organization and the functioning of the BA in Algeria while the second part exposes the arguments in favor of the "necessity" to create a BA in the fortified towns of the north of Africa. ${ }^{7}$ The report concludes with a strong recommendation for the creation of Oficinas Ârabes as important instruments or "centers of penetration" in the Territories and Dominions of North Africa.

\section{Myths construing other myths}

It is perhaps necessary to emphasize some of the aspects that favored the preservation of myths during the North African colonial period. First of all, the relative absence of Berber historians, until the postcolonial period, means we

6 Article VII, Decree of 29 December 1931 which regulates the reorganization in the zone (of the North of Morocco).

7 Many thanks to Mr. Vicente Moga Romero, Director of the municipal Archives of the autonomous city of Melilla, Spain, who kindly made available to me a copy of the quoted report from Cándido Lobera Girela. 
have to deal with an exclusively external vision and interpretation of the different myths surrounding these people. The "Berber myths" do not originate, however, during the colonial period. They have accompanied Berbers throughout recorded history from as far back as Antiquity as attested in the stories of Herodotus about North Africa and the Libyans, identified early on as fiction (Tissot 1877). These myths would continue to be believed through to the medieval period thanks to the descriptions of the Arabic geographers (McDougall 2010; Norris 1982; Shatzmiller 1984; Talbi 1973; Tilmatine 2008, 2009/2010). A glance at the historic documents in relation to France's so called Berber policy reminds us that it is not obvious that the "myth" was sufficiently politically motivated as to appear in different publications and papers. By way of example, to my knowledge, there are no documents of the French or Spanish governments advocating improvement of the situation of the Berbers over that of the Arabs.

Regarding the ideology of the BA, according to Yver (1955: 570), it appears they based their activities on general principles and basic ideas which constitute, what Yacono calls, the "doctrine" of the Arabic offices (Yver 1955: 570). It is useful, however, to remember that this doctrine was not codified in administrative texts but that it manifested itself easily through the positions or activities of individual officers in their endeavor to apply it. A brief look at the different arguments developed in the specialized literature is sufficient to put into perspective some of the various themes that served as a vehicle for Berber policy and Kabyle myth.

\subsection{Berber policy and Kabyle myth}

The manner in which Moroccan Berbers were praised reproduced exactly the long and illustrative defense of the Algerian Kabyles. Berber policy in Morocco was based "on an old berberophile option which would become topical in Morocco and contribute to the formation of yet a new Berber myth" (Ageron 1971: 51).

Specialists in the history of the colonial period consider declarations such as "the Moroccan people are not Arabic" as myth and untruth. Such clichés are so well-known that they can be qualified as typical stereotypes in the Algerian colonial literature (Ageron 1971: 51).

Nevertheless, developments of recent years in the North African countries, especially in Algeria and Morocco, have shown that Berber demands are indeed being met, including correction of history textbooks used in secondary education which erroneously depict these countries as exclusively Arabic (Tilmatine 2007: 243). 
This trend is also true of other countries such as Libya since the fall of the Gaddafi Regime and the explosion of identity-based and linguistic demands in the Berber speaking regions. The demands of the Berber people have also reached, on the national and international level, highly symbolic fields such as onomastics. Indeed, the name Maghreb arabe [Arab Maghreb] has now been rejected, not only by the militant Berber and associative groups, but also certain official circles. According to media sources, the Moroccan Foreign Minister, Saâdeddine El Othmani, during the meeting of Ministers of Foreign Affairs of the Arab Maghreb Union in Rabat in 2012, surprised his Maghreb counterparts by inviting them to eliminate the term "Arab" from the name "Arab Maghreb Union". 8 This trend is also beginning to affect diverse levels of the civil society and the North African political parties. ${ }^{9}$

The same is true of another basic premise, also now understood, especially in Berber militants and cultural circles, as an untruth and a myth of the famous Berber policy (Cf. Section 1.4.): The Moroccan people remained a very superficially Islamized, and very partially Arabized, Berber unit.

Recent events in both Morocco and Algeria, and also even in Libya, have revealed that this Berber block is alive and well, and going from strength to strength.

\subsection{Berbers and Islam}

The discourse surrounding Berbers and their relationship to Islam is another confusing issue.

On one hand, the Berber myth lauds their de-Islamization and warns of their Arabization. Instructions recommended to the French officers "not to arabize these Berbers by imposing upon them the Koranic Sharia, giving them Qadis [Moslem Judges], and decreasing the importance of their jmâ'a-s [assemblies or councils of tribal elders and notables]” (Ageron 1971: 57). Others like General Brémond made no effort to conceal the need to "de-Islamise the Berbers and to Gallicize them" (quoted by Ageron 1971: 57). The Freemasons believe that we can expect much "from the educated Berbers in order to counterbalance the Muslim fanaticism influence" and that we must "avoid the eviction of the Customary law as defense against the Koranic law". ${ }^{10}$

8 http://www.demainonline.com/2012/11/13/le-maroc-veut-supprimer-ladjectif-arabe-de-luma/. 9 http://www.lemag.ma/Maroc-Un-parti-du-gouvernement-veut-supprimer-le-mot-Arabe-dunom-de-la-MAP_a78268.html or also: http://www.businessnews.com.tn/Rafik-Abdessalem-pro voque-la-col\%C3\%A8re-des-amazighs-maghr\%C4\%82\%C2\%A9bins,520,29502,3

10 «Les Francs-Maçons au Maroc sous la IIIe République 1867-1940 », Chapitre IV, http:// emsomipy.free.fr/Maroc128.042-1929ApogeeDahirBerbere.htm 
On the other hand, however, it seems that "the BA do not adopt a hostile policy to Islam and, in Kabylia in particular, Islamization was considered a step toward civilization, a relative raising of the moral standards of the natives and, consequently, a means to improve government activities" (Yacono 1992: 1660).

Certain high-ranking officers of the BA, on the topic of Christianization of the Berbers, went as far as declaring that "evangelization appeared as a danger and the Arabic office challenged the missionaries", and on that point Mgr. Lavigerie held Hanoteau responsible for the failure of his "evangelization policy". However, the widespread assertion that the Dahir intended to alienate Berbers from Islamic law is "empirically untenable on several points" (Hoffman 2010: 858).

\subsection{The myth of Arab North Africa and its Arabization}

Surprisingly, some of these myths have survived throughout history, e. g. the supposed religiosity of Berbers. Yet another myth would be born among the Arabs: Berbers, or at least certain Berber tribes, are claimed, by the author Ibn Khaldoun, to be genetically linked to the Arabs. He further claims that North Africans were all Arabs during the colonial period, especially during that of the Arabic Empire of Napoléon III. Following independence, post-colonial governments would continue developing the Kabyle myth or the Berber policy of France. The discourse from France, and subsequently Spain and other colonial powers, reinforced that of local ruling dynasties and directed them to the East and Arabo-Islamism, where they would define themselves exclusively as AraboIslamic. This then contributed to the establishment of an even more convincing myth, that of the "Arabic Nation", of which Algeria and the other countries of North Africa would fall prey. Thus the Algerian national charter of 1986 would openly state that the Algerian people are Arabic and Muslim (Sanson 1985: 77).

For the BA the creation of Arabic-French schools in Algeria appeared to be the solution to the problem of the Koranic schools, in which they saw "homes of fanaticism" and "meeting places of the most relentless enemies of our domination" (Yacono 1992: 1664). The famous White Fathers also opened several schools in 1872 in the same region.

This process of Arabization, according to Moulieras (1899), was readily predictable early on in Morocco. The author, in a descriptive vision of the future depicted the Djebala tribes bordering the Rif-Region of North Morocco, as irreversibly adopting the Arabic language and "not wanting to hear any more about their Berber origins", and predicted that "genealogists will prove, with striking clarity, that they are descended from a famous warrior of Hidjaz or from Iraq", and that "these new recruits would in their turn want to arabize Rif, to 
eradicate their old idiom, their customs and their ancestors”. The author visualizes how the annexation of Morocco to a European power would be carried out much more quickly and effectively than occurred in Algeria: "then the Arabization of the entire Berber population of the Empire would advance in great strides. The conquering nation would be the first to favor the metamorphosis, as we have in Algeria, due to our utter ignorance of the ethnography and the history of the Barbary States" (Moulieras 1899: 306). The White Fathers and officers of the BA were not the only ones, however, to support Arabization. Beyond the period of Napoleon III, arabophile circles constituted, along with the Arabists, a favorable current which contributed to the imposition of Arabic as the sole language of education: "In Algeria [...], key positions are in the hands of those who represent the arabophile current. So [...] that the government entrusted (to them) the management of the new Arabic-French imperial Middle School (college) of Algiers (1857), followed by the first General Inspectorate of the Arabic-French schools in Algeria (1863)” (Messaoudi 2009: 4).

In the same vein, Arabic was still, at the beginning of the 1850s, the only foreign language taught in the Middle School of Algiers. It appears that the Arabic language held such a strong monopoly that the vice-Chancellor resorted to opposing the teaching of English and German for fear of competing against it (Messaoudi 2009: 4).

\subsection{Favored treatment for Berbers?}

Finally, another myth which requires deconstruction is the fact that the Berber policy or the Kabyle myth are still presented as a framework favoring the Berber languages as along with their development as languages of instruction. However, interest in the Amazigh languages has been reduced to just one purpose: the acquisition of an instrument of communication or, according to Muñoz Bosque's explanation (Prologue: 5), the way to "penetrate into the heart of the local populations and gain their intimacy and trust".

North African arabness was, especially during the period of Napoléon III, one of the points often developed in the literature regarding the Berber myth. Many defended the argument that North Africa was immune to Arabization. In fact, apart from French however, Arabic, as non-native, was the only obligatory language in the education system in spite of the fact that it was not the mother tongue of the Berber people: "[...] it is true that few knew the Arabic language well, and those who did often felt reluctant to speak it” (Yacono 1992: 1664).

The colonial powers were never interested in the Amazigh languages as native languages of a population, nor in developing them in order to promote their role as 
vehicles of expression, education, economy or, simply, daily use. Education was carried out in Spanish, French or Arabic; Kabyle and Riffian Berber were neither subjects taught in school nor the language of instruction. In no court was it possible to speak Amazigh nor was any journal or magazine ever published in Amazigh during the entire colonial period that lasted 44 and 132 years, in Spanish possessions in Morocco and Algeria respectively. On the contrary, the Arabization of the Berber speaking areas began with the implantation of the BA especially in the onomastic field, for instance, anthroponomy and toponymy.

More generally and regarding the Berber Movement and its adherents, it needs to be stated categorically that the entire discourse surrounding the text of Berber Dahir of 1930 pertaining to the Christianization of the Berber people and their consequent rejection of Islam and the breakdown of the country are simply unfounded and must be refuted as a result of a distorted interpretation of history (Mounib 2002).

\subsection{Linguistics and colonialism}

There has been considerable research carried out on linguistics and colonialism (Errington 2008; Oestler 2006), the development of language empires (Hamel 2006), linguistic imperialism (Phillipson 2009), death of languages (Calvet 1974; Crystal 2000; Hagège 2000), reversing language shift, and languages of minorities (Fishman 1991). Few of these topics, however, correlate to the specific situation in North Africa. Interestingly, apart from the "francization" attempts, which are most evident in Algeria, the colonial linguistic policies rely much more heavily on the Arabization of the region. In that context, it is of interest to evoke the role played by France and Spain in the spread of the "Arab North Africa" myth.

In that respect, French and Spanish colonialism was interested in local languages not as “a set of practices and performances" (Calvet 1999: 165), but merely as objects of knowledge, serving exclusively their own interests and completely ignoring the fact that the study of a language must take into account the relationship of language and environment. In other words, foremost consideration must be given to the relationships between languages of the country (Berber and Arabic), and to the status of these languages within the society: mother tongue, local and unofficial languages vs. acquired or taught, external but official languages (French and Spanish respectively).

So why give so much credence to Arabization? Firstly, from an ideological view point, France and Spain, countries traditionally with a centralizing linguistic ideology, cannot allow peripheral languages such as Berber to play a significant role, but can readily envisage the role of a "super central language" 
such as Arabic. Arabic may be considered a second-rank language in the schedule proposed by Hamel (2010:6) and is identified as such by Swaan (1993: 220).

The relationship between languages and religions has also been well documented. ${ }^{11}$ However in the case of Arabic, apart from its role as dominant language, we need to take into account its additional value as the sacred vehicle of Koranic teaching.

Therefore, and in contrast to other colonial languages such as French or English, the expansion of Arabic has relied fundamentally on religion. Herein lies the basis of the Arabic domination of North Africa, which began with the arrival of the Arabs and the islamization of North Africa in the seventh century. This process has continued to the present day by leaning on two fundamental pillars. The first, Islamic legitimacy, feeds off the inextricable relationship between Islam and Arabic which became stronger during the colonial period. The second, nationalist legitimacy, came to the fore following the independence of the North African countries.

\section{Concluding comments}

The majority of the works pertaining to colonial North Africa focus on "Berber stereotypes" by underlining the constructed oppositions and categories, created according to this literature to divide the country into ethnic groups benefit their policy of divide and conquer.

Even knowing this myth was based on simplistic oppositions between Arabs and Berbers (Berque 1956: 322-323), the overwhelming majority of academic studies consider the Kabyle and Berber myth as historical fact to be rejected and criticized since it favored Kabyles and other Berbers over Arabs (Lorcin 1995: 84, 85).

Actually, these interpretations concerning the Arab-Berber dichotomy are often excessive. Simply stating that these categories are artificial constructs and accusing them, rightly so, of being "untruths about an obvious fact" (Ageron on 1971: 54) does not cause them to cease to exist. Furthermore, to enumerate these "untruths" in Algeria or Morocco does not prevent them from still being perceived as real. In presenting them, the majority of authors demonstrate little concern whether they actually correspond to any reality.

11 Cf. for example the position of Fishman in this issue in his co-edited research with Tope Omoniyi (Omoniyi and Fishman 2006) and more generally Fishman's contributions to international sociolinguistics resumed in García et al. (2006). 
In summary, the colonial period bequeathed us a "Kabyle (or Berber) myth" which attributes certain qualities to this population which are blatantly false. Certain academic circles, generally close to the so called "arabo-islamist" ideology, would deny any specificity to the Kabyles and reject even the idea of a particular geographic space (Abdelfattah Lalmi 2004). This myth had to be confronted - firstly during the colonial period, then by European and North African academics. These ideas would be taken up with more virulence after the North African countries gained independence, not only by the official discourse but also by several North African researchers who would relentlessly deny Berber specificities in Morocco and in Algeria, in particular in the region of Kabylia. It was then that another ever more sinister myth arose - born in the shadow of the Kabyle myth and nourished by it - the myth of North African countries that would define themselves as exclusively Arabic and Muslim. The consequences of that myth on the future of North Africa were beyond measure.

Ironically, the current developments and the political choices in Berberspeaking regions seem to consolidate to a large extent the ideas of the Kabyle myth or the Berber policy. Moreover, it is interesting to notice a certain return of this myth which conceptualizes Arab/Berber ethnic differences as primordial, not only in the current debates on the identity claims in Kabylia but also in the diaspora in France (Vincent Geisser and Aziz Zemouri 2007). It appears that the current North African governments are now achieving what the French Berber policy couldn't achieve during the colonial period.

The writing is on the wall: the specificities of Berber cultures and their attachment to traditional forms of organization (Tada, Archs) $)^{12}$ are coming to the fore; political Islam and Arabization policies are being met with opposition; the first signs of disaffection with Islam and Muslim practices, on one hand, are being observed; evangelization campaigns in Berber-speaking zones, on the other hand, are enjoying unprecedented success. ${ }^{13}$

Finally, on the ideological level, since the advent of the Berber movement in the 1980s, we have experienced a pressing demand for secularism and its endorsement in the charters of the Berber protest movements in various berberophone countries (Ben-Layashi 2007; Silverstein 2007).

The intense expressions of deep distrust in the central government have led to the formation, over recent years, of the "Movement for the Autonomy of Kabylia", which then transformed in 2013 into the "Movement for Self-Determination of Kabylia”.

12 About the term Tada [ceremony of colactation] cf. e. g. Marcy (1936) and Belghazi (1998, 2003). About the term Archs [Tribes of Kabylia], cf. Allioui (2006).

13 Cf. the public breakfast organized during Ramadan in Tizi Ouzou, Kabylia on 3 August 2013. 
Could we be approaching independence? Even though that hypothesis may seem a distant and unrealistic possibility for many, the fact remains that an independent Kabylia was already anticipated as far back as the colonial period (Alexis de Toqueville 1847: 7). Perhaps it will see the light of day now under the current post-colonial Algerian State, despite her policies of exclusion and repeated denials of the linguistic and cultural rights of the Berber peoples.

\section{References}

Abdelfettah Lami, Nedjma. 2004. Du mythe de l'isolat kabyle. Cahier d'études africaines 175. 507-531.

Ageron, Charles-Robert. 1960. "La France a-t-elle eu une politique kabyle? Revue Historique 223

(Fasc. 2). 311-352. Paris: Presses Universitaires de France. Stable URL: http://www.jstor. org/stable/40950595 (accessed 16 May 2013).

Ageron, Charles-Robert. 1968. Les Algériens musulmans et la France 1871-1919, vol. I. Paris: P. U.F. (267-277).

Ageron, Charles-Robert. 1970. Abd el-Kader souverain d'un royaume arabe d'Orient. Revue de l'Occident musulman et de la Méditerranée 8. 15-30.

Ageron, Charles-Robert.1971. La politique berbère du protectorat marocain de 1913 à 193. Revue d'histoire moderne et contemporaine (1954-) 1 (18). 50-90.

Allioui, Youcef. 2006. Les archs. Tribus berbères de kabylie. Histoire, résistance, culture et démocratie. Paris: L'Harmattan.

Belghazi, Hammou. 1998. Tadâ, un pacte sacre de pondération tribale. Études et documents berbères, 15-16. 141-151.

Belghazi, Hammou. 2003.Tada : puissance et évanescence : recherche sur la mutation du mode d'existence des Zemmour : contribution à l'étude du changement social dans le Maroc rural. Thèse de doctorat en Sociologie. Besançon. http://www.theses.fr/2003BESA1023

Ben-Layashi, Samir. 2007. Secularism in the Morocco Amazigh Discourse. Journal of North African Studies 12(2). 153-172.

Berque, Jacques. 1956. Cent vingt-cinq ans de sociologie maghrébine. Annales ESC XI 3. 296-324.

Boudraa, Nabil \& Joseph Krause (eds.). 2007. North African Mosaic. A cultural reappraisal of ethnic and religious minorities. New Castle: Cambridge Scholars Publishing.

Calvet, Louis-Jean. 1974. Linguistique et colonialisme, petit traité de glottophagie. Paris: Nathan.

Calvet, Louis-Jean. 1999. Pour une écologie des langues du monde. Paris: Plon.

Daumas \& Fabar. 1847. La Grande Kabylie. Études historiques. Paris-Alger: L. Hachette et $C^{\text {ie }}$. Errington, Joseph. 2008. Linguistics in a colonial world: A story of language, meaning, and power. Malden: Blackwell Publishing.

Crystal, David. 2000. Language death. Cambridge: Cambridge University Press.

De la Torre del Rio, Rosario. 2007. Preparando la conferencia de Algeciras: el acuerdo hispanofrancés de 1 de septiembre de 1905 sobre Marruecos. Cuadernos de Historia Contemporánea, Vol. Extraordinario. 313-320.

Fishman, Joshua Aaron. 1991. Reversing language shift: Theoretical and empirical foundations of assistance to threatened languages. Clevedon \& Philadelphia: Multilingual Matters 
Foucher, Victor. 1858. Les bureaux arabes en Algérie. Paris: Librairie internationale de l'agriculture et de la colonisation.

Francs-Maçons au Maroc sous la Ille République 1867-1940 (Les). http://emsomipy.free.fr/ Maroc128.151-TableMatieres.htm (accessed 12 February 2014).

Garcia, Ofelia, Rakhmiel Peltz \& Harold Schiffman. 2006. Language loyalty, continuity and change. Joshua A. Fishman's Contributions to International Sociolinguistics. Clevedon: Multilingual Matter Ltd.

Geisser Vincent \& Zemmouri Aziz. 2007. La renaissance du mythe kabyle. Article de la Rubrique les deux rives de la Méditerranée. Ligue des Droits de l'Homme. Toulon. http://ldh-toulon. net/la-renaissance-du-mythe-kabyle.html (accessed 22 April 2014).

González, Irene. 2012. El ejército, actor de la política educativa española en el Norte de Marruecos durante el protectorado (1912-1956). Revista de Historia militar, Número extradordinario II. 69-100.

Hacoun-Campredon, Pierre. 1921. Étude sur l'évolution des coutumes kabyles spécialement en ce qui concerne l'exhérédation des femmes et la pratique du hobous. Alger: Jourdan, Jules Carbonel.

Hagège, Claude. 2000. Halte à la mort des langues. Paris: Odile Jacob.

Hajji, Abderraouf. La question berbère en 3 ans. Chapitre 14. Le Maroc face aux aléas de l'histoire. Published online. http://said.hajji.name/fr/book-berb3ans.html. (accessed 23 April 2014 20:22:22).

Hamel, Enrique Rainer. 2006. The development of Language Empires. In Ulrich Ammon, Norbert Dittmar, Klaus J. Mattheier \& Peter Trudgill (eds.), Sociolinguistics. Soziolinguistik. An international handbook of the science of language and society, vol. 3, 2240-2258. Berlin \& New York: Walther de Gruyter.

Hamel, Enrique Rainer. 2010. L'aménagement linguistique et la globalisation des langues du monde, Télescope 16(3). 1-21.

Hart, David M. 1997. The Berber Dahir of 1930 in colonial Morocco: Then and now (1930-1996). The Journal of North African Studies 2(2).11-33.

Hart, David. 1999. Spanish colonial ethnography in the rural and tribal nothern zone of Morocco, 1912-56: An overview and an appraisal. Journal of North African Studies 4(2). 84-102.

Hoisington, William A. 1978. Cities in revolt: The Berber Dahir (1930) and France's urban strategy in Morocco. Journal of Contemporary History 13(3). 433-448.

Hoffman, Katherine, E. 2010. Berber law by French means. Berber courts in Moroccan Hinterlands (1930-1956). Comparative Studies in Society and History 52(4). 851-880.

Hoffman, Katherine E. \& Susan Gilson Miller (eds.). 2010. Berbers and others. Beyond tribe and nation in the maghrib. Bloomington: Indiana University Press.

Kaddache, Mahfoud. 1972. L'utilisation du fait berbère comme facteur politique dans l'Algérie coloniale. In Micheline Galley \& David R. Marschall (eds.), Actes du Premier Congrès d'Études des Cultures Méditerranéennes d'Influence Arabo-Berbère, 272-284. Alger: SNED.

Kampffmeyer, Georg. 1934. Der Widerhall des Berber-Dahirs in der Islamwelt. Die Welt des Islam 15(3/4). 74-86.

Koller, Ange. 1949. Essai sur l'esprit du Berbère marocain. Fribourg: Éditions franciscaines. Lafuente, Gilles. 1994. Dahir berbère (16 Mai 1930). Encyclopédie Berbère XIV - Conseil Danse. Paris: Edisud. 2178-2192. 
Lafuente, gilles. 1999. La politique berbère de la France et le nationalisme marocain. Paris: L'Harmattan.

Levallois, Michel. 2001. Une autre conquête de l'Algérie. Ismaÿl Urbain (1812-1884). Paris: Maisonneuve et Larose.

Lobera Girela, Cándido. 1905. Memoria sobre la organización y funcionamiento de las Oficinas de Asuntos Árabes de Argelia. Proyecto de bases para la creación de organismos análogos en las plazas del Norte de África. Melilla: Tipografía El Telegrama del Rif.

Lorcin, Patricia M.E. 1995. Imperial identities: Stereotyping, prejudice and race in colonial Algeria. London \& New York: I.B. Tauris.

Maddy-Weitzman, Bruce. 2011. The Berber Identity Movement and the Challenge to North African States. Austin: University of Texas Press.

Mammeri, Mouloud. 2005. Cheikh Mohand a dit. Inna-yas Ccix Mohand. Alger: Centre National de Recherches Préhistoriques Anthropologiques et Historiques (CNRPAH).

Marcy, Georges.1936.. L'alliance par colactation (tâd'a) chez le Berbères du Maroc central. Revue Africaine 79. 957-973.

McDougall, James. 2003. Myth and Counter-Myth: «The Berber» As National Signifier in Algerian Historiographies. Radical History Review 86. 66-88.

McDougall, James. 2010. Histories of heresy and salvation: Arabs, berbers, community, and the state. In Katherine E. Hoffman \& Susan Gilson Miller (eds.), Berbers and others. Beyond tribe and nation in the maghrib, 15-37. Bloomington: Indiana University Press.

Messaoudi, Alain. 2009. Les arabisants français et la 'réforme' en Afrique du Nord. Autour de Louis Machuel (1848-1922) et de ses contemporains. In Odile Moreau (ed.), Réforme de l'État et réformismes au Maghreb (XIXe-XXe siècles), 235-259. Paris \& Tunis: L'Harmattan/ Publications de l'IRMC.

Mouliéras, Auguste. 1899. Le Maroc inconnu, 2ème partie (Exploration du Djebala). Paris: Augustin Challamel Editeur.

Mounib, Mohamed. 2002. Aḍ-ḍahîr "al-barbarî". Akbar Ukdûba siyâsiyya fî-l-Magrib almuYâșir. Rabat: Dar Bou Regreg.

Mouslim, Barbari. 1931. Tempête sur le Maroc ou les erreurs d'une "politique berbère". Paris: Editions Rieder.

Muñoz Bosque, Ángel. Manual de conversación bereber rifeña. Estudio práctico de la lengua berber xeljha o zamácijz del Rif, s.l., s.a., s.i., 59 p.

Nait-Djoudi, Oulhadj (2001). L'exhérédation des femmes en Kabylie: le fait de l'histoire et de la géographie. Insaniyat 13. 187-201.

Norris, H. T. 1982. The berbers in Arabic literature. Harlow: Longman.

Omoniyi, Tope \& Joshua Aaron Fishman. 2006. Explorations in the sociology of language and religion. Discourse Approaches to Politics, Society and Culture 20. Amsterdam \& Philadephia: John Benjamins Publishing Company

Ostler, Nicholas. 2006. Empires of the word: A language history of the world. London: Harper Perennial.

Patorni, F. 1895. Délibération de l'année 1749, dans la Grande Kabylie. Revue africaine 39. 315-320.

Phillipson, Robert. 2009. Linguistic imperialism continued. New York \& London: Routledge.

Renan, Ernest. 1873. Rapport sur les travaux du Conseil de la Société asiatique pendant l'année 1872-1873, fait à la séance annuelle de la Société, le 28 juin 1873, par M. Ernest Renan. Journal Asiatique, septième série, tome II. Paris: L'Imprimerie Nationale. 11-81. 
Rey-Goldzeiguer, A. 1977. Le royaume arabe. La politique algérienne de Napoléon III, 1861-1870. Alger: SNED.

Rivet, Daniel. 1991. Le rêve arabe de Napoléon III. L'Histoire 140. Published in http://www. napoleontrois.fr/dotclear/index.php?post/2006/04/05/127-le-reve-arabe-de-napoleon-iii. (Accessed 10 Janurary 2014).

Sanson, Henri. 1985. Peuple algérien, peuple arabe. Annuaire de l'Afrique du Nord XXIV. 75-88.

Shatzmiller, Maya. 1984. Le mythe d'origine berbère: Aspects historiographiques et sociaux. ROMM 35. 145-156.

Silverstein, Paul A. 2007. Islam, Laïcité, and Amazigh Activism in France and North Africa. In Nabil Boudraa \& Joseph Krause (eds.), North African mosaic. A cultural reappraisal of ethnic and religious minorities, 104-118. New Castle: Cambridge Scholars Publishing.

Spillman, Goerges. 1972. Le Royaume arabe d'Algérie. Revue du Souvenir Napoléonien 266. 15-19. http://www.napoleon.org/fr/TemplatePrint/article.asp?idPage $=437967$. (accessed 11 January 2014).

Swaan, Abram de. 1993. The emergent world language system: An introduction. International Political Science Review 14(3). 219-226.

Talbi, Mohammed. 1973. Hérésie, acculturation et nationalisme des Berbères Bargawata". In Premier congrès des cultures méditerranéennes d'influence arabo-berbère, 217-233. Alger: SNED.

Tilmatine, Mohand. 2001. "Les études berbères sous le protectorat espagnol (1912-1956)". In: Etudes berbères, Dymitr Ibriszimov y Rainer Vossen (eds.) Afrikanistische Blätter 13. 153-182.

Tilmatine, Mohand. 2007. "Du Berbère à l'Amazighe: de l'objet au sujet historique". Al-Andalus-Magreb 14. 225-247.

Tilmatine, Mohand. 2008. Altérité et Marginalisation. Les Berbères dans l'Époque médiévale. Awal - Cahiers d'études berbères 38. 23-30.

Tilmatine, Mohand. 2009/2010. L'image des Berbères chez les auteurs arabes de l'époque médiévale. Awal 40-41. Créer et transmettre chez les Berbères. 171-183.

Tissot, Charles Joseph. 1887. La Libye d'Hérodote (pl. XI, XII) (Cf. p. 264). Bulletin de correspondance hellénique 1. 265-273.

Tocqueville, Alexis de. 1847. Premier Rapport sur l'Algérie. Extraits du premier rapport des travaux parlementaires de Tocqueville sur l'Algérie en 1847. http://classiques.uqac.ca/ classiques/De_tocqueville_alexis/de_la_colonie_algerie/rapport_sur_algerie/rapport_ sur_algerie.html (accessed 09 February 2014).

Urbain, Ismaÿl. 1861. L’Algérie pour les Algériens. Alger: Michel Levy Frères.

Valderrama, Martínez, Fernando. 1956. Historia de la acción cultural de España en Marruecos (1912-1956). Tetouan.

Villanova, José Luis. 2005. La pugna entre militares y civiles por el control de la actividad interventora en el protectorado español en Marruecos (1912-1956). Hispania LXV/2 (220). 683-716.

Yacono, Xavier.1953. Les Bureaux arabes et l'évolution des genres de vie indigènes dans l'Ouest du Tell algérois (Dahra, Chélif, Ouarsenis, Sersou). Paris: Larose.

Yacono, Xavier.1992. Bureaux arabes. Encyclopédie Berbère (XI). Aix-en-Provence, 1657-1668.

Yver, Georges. 1955. Méthodes et institutions de colonisation: les bureaux arabes. Annales. Sociétés, Économies, Civilisations 4. 569-574. 